\title{
Phraseological units in the Tatar language containing the component of can (küñel) (SOUL)
}

\author{
Damir H. Husnutdinov - Ramilya K. Sagdieva - Flera S. Sayfulina - \\ Rinat G. Gatin - Aynur A. Timerkhanov
}

DOI: 10.18355/XL.2019.12.02.04

\begin{abstract}
In the modern Tatar linguistics, a great interest is manifested to studying the language as a unique cultural code of particular linguocultural communities. Phraseological combinations used in the Tatar poetry that have direct lexical equivalents in the language can be extended in the contest due to the same circumstances as their lexical equivalents. The meaning of a combination itself is not replenished in any way, but such extension of boundaries of stable phrases can affect its meaning in a certain context by contributing additional sense aspects into it, which are absent in its general language variant. An attempt to discover the national identity of emotional sensations of the Tatar people is made in this article by using such general research methods as induction, deduction, observation, as well as analysis and synthesis of empirical materials. Phraseological units of the Tatar language with emotionally expressed components have been analyzed, which makes it possible to assess and evaluate how the Tatar people imagine and visualize the world. The findings of this research prove that in the Tatar linguistic vision of the world, as well as in the Eastern linguistic culture, the human, his emotions and speech are striving for harmony by mutually complementing each other. Tatars' life, routines, and emotions appear to be seriously influenced by Islamic traditions. The significance based upon a comprehensive analysis of phraseological units reveals the national specific vision of the world, the methods for nomination and segmentation of the emotional world, as well as the human image featured in the Tatar language phraseology. The research findings make it possible to represent such significance for the general theory of linguistic science.
\end{abstract}

Key words: phraseological unit, expressive and emotional vocabulary, emotions, Tatar language, emotional condition

\section{Introduction}

Over the last several decades, more and more specialists in various fields are becoming focused on the emotional aspect of the human. Human emotions are the research object of literary historians since literary works, especially poetry, disclose the spiritual world of people. Attention to the inner state of a person, to his feelings, experiences, and thoughts is one of the traditions of Tatar classical literature formed at the beginning of the twentieth century, Tatar literature of this period characterized by deep psychological analysis of the soul's state.

(Gilazov T.Sh. et.al., 2015; Yusupova N.M., et.al., 2016; Ibragimov Bulat Kh, et.al., 2017; Sibgaeva F.R., et.al., 2015; Gabdrakhmanova F.H., et.al., 2016; Husnutdinov D.H., 2014; Husnutdinov D.H., et.al., 2016; Fayzullina, G.Ch., et.al., 2016).

Emotions are considered as the key categories of psychology. However, emotions are currently being actively studied in the area of linguoculturology (Shadrikov, 2014; Krasavsky, 2016; Rodionova, 2011).

The object of linguocultural science is the study of the interconnection of the language and culture of people. As a result, it forms the national picture of the world. Moreover, the concepts of the language are reflected in folklore, mythology, and literature. The study of the linguistic world-image helps to reveal the patterns inherent in the language and national-cultural thinking of its native speakers, to disclose the

XLinguae, Volume 12, Issue 2, April 2019, ISSN 1337-8384, eISSN 2453-711X 
conceptual meaning of a separate word. The study of the Kunel (soul) concept will help to reveal the lexico-semantic field of the given word, to determine the place of this word in the creation of the national picture of the world.

The meanings of the terms "emotion", "feeling", "affectus" are not strictly fixed; and there is no common understanding or clear terminological boundaries in the use of these related concepts in the science. The domestic scientists tend more and more to use the word "emotion" as a generic term. Scientists see the complexity of studying the vocabulary expressing emotions in their abstractness, fluidity, and elusiveness in the language (Yiğit and Tarman, 2016). The ability to react to surrounding phenomena with emotions is a natural human feature, and it does not depend on a person's culture or linguistic origin (Ayupova, 2015). Therefore, the vocabulary reflecting the emotional condition contains general concepts, and it is not so simple to detect their specific features. R.R. Zamaletdinov also formulated this specificity: "Research into emotional concepts, attempts to systemize and describe them will enable us to expand the vision of the semantic field of 'emotional concepts', and it will make it possible to distinguish comprehensive and linguo-specific features in the methods for their conceptualization and functioning; it will empower us to study more thoroughly the mentality of native Tatar and, more widely, Turkic speakers. The scientists studying the emotional and sensational side of the human highlight some blurring in its constituent segments which are difficult to clearly identify" (Denmukhametova, 2016: 67).

The analysis of phraseological units expressing emotional states is of great importance for modeling the internal world of the human. Emotions exist and function variously in different peoples. In the Tatar linguistics, scientific works were dedicated to emotional sensations by Sh.A. Ramazanov, G. Akhatov, G.Kh. Akhunzyanov, G.S. Amirov, F.S. Safiullina, L.K. Bayramova, R.A. Yusupova, G.K. Gizatova, G.Z. Sadykova.

This article features phraseological units with emotional tones in the Tatar language.

The purpose of this research is the semantic reconstruction of the Tatar people's national vision of the world in the aspects of emotions expressed through phraseological units.

\section{Materials and Methods}

This scientific work contains analysis and synthesis of the empirical materials, their generalization, and classification. The basic research method was the method of monitoring the linguistic material. This method includes research into factual material, as well as synthesis, interpretation, and classification. Selecting phraseological units toned with human emotional sensations. The practical material was classified based on the structural and semantic analysis. Such special linguistic methods as the method of semantic analysis, the linguistic description method, the thematic classification method and the method of statistic analysis were also used.

\section{Research}

Research into lexico-semantic features of phraseological units in the Tatar language is very significant for studying the development stages in the mentality history which were associated with sociological issues of forming the people's culture, and for clarifying the organic link between artistic and aesthetic aspects of thinking. These can form the basis for analyzing the semantic development of the Tatar phraseology.

Emotions in the Tatar language are denoted with the terms «xis» (feeling), «toyğı» (emotion), «kiçereş» (sensation) which represent the human's inner world. The substance of the human's inner world is «can» (soul).

«Can» (soul) is an attribute of a living being, a source, a symbol of human life. At any time, can can freely leave a person, especially during sleep, it can wander for a while, and then return to the body again. If can does not come back, the person dies. "As 
Tatars imagine, the soul can sometimes leave the person. It usually occurs while a person is unconscious, comatose or asleep, but it comes back to him after awakening" (Bulgarova and Islamova, 2017: 28).

Tatars imagine that the characteristic feature of the soul is its ability to fly, to soar: qübäläq can (literally: soul like a butterfly); can kanatlanu (winglike soul); can oçu (the soul is flying), etc.

There exists a phrase in the folklore: «Canı cännättä bulsin!» / «Canbl ocmaxta bulsin!» (Let the soul rest in Paradise!). The people denoted the place where the souls of righteous persons happily exist with the word «cännät/ocmax» (Paradise).

The people's consciousness has a fixed concept of the soul as a binding link between the man and the higher world. It is the presence of soul that indicates human viability: can alu, can birü (literally: to take and give soul) - a condition when a human is between life and death; can saklau (literally: to protect soul) - to struggle for life, to live, to exist; canın alu (literally: to take soul) - to die, to kill; can birü (literally: to give soul) - to die and to gasp out life (Mugtasimova, 2016: 255).

The Tatar language phraseology contains the following conceptual synonyms to the lexical unit «can»:

mäxäbbät - can (love - soul): can söygän (beloved lady); mäxäbbät öçen can fida qılu (literally - to sacrifice one's soul for love);

rux - can (spirit - soul): cılı süz - can azığ l(iterally - a kind word - food for thought);

yöräk - can (heart - soul): çıkmağan canda ömet bar (literally - if the soul remains, hope still exists); kurkudanн yöräk yarılu (literally - frightened heart cracked);

tınıçlık - can (peace - soul): canbına yon üskän (peaceful soul); tınıç can (serene soul);

kurku - can (fear - soul): can siker (literally - the soul is jumping out); can oçu (literally - the soul is flying);

künel - can (spiritual world - soul): kalğan küñel - çıkkan can (literally: offended soul - abandoning soul).

Can often indicates the person's inner world and conveys (contains) such human emotions as love, fear, happiness, anger, sadness, etc.: can ärnü (suffering, soul bitterness), can öşü (chill, coldness of soul), can sızlau (pain, the soul is aching), can äçese (soul bitterness, offense), can sıktau (soul weeping), can räxäte (delighted soul, emotional satisfaction, good humor) etc.

Apart from the basic meaning, «can» has also other semantic meanings: canın careless of life; canı bar - alive; canza yakın - intimate to soul, akin; eçtä can bulu as long as I am alive; tere can - alive person, alive soul; can azlğ - food for thought; can başı - for everyone; can dus - close friend; can açuı - anger; can atu - striving; can alu - to deprive of life, to kill; can koyu - to be unsatisfied; can kuu - to die; can söygän - beloved etc.

In the Tatar people's imagination, the soul exists in different human organs. According to the Tatar phraseology, the human soul is located depending on what feelings are experienced by the person, and such locations can be the heart, soul, hands, thighs, fingertips and nose tip: canı borın oçında (literally -the soul on nose tip); canı botına töşte (literally - the soul hidden in thighs); canı uçında (literally - the soul in hand).

The soul can be wounded or injured: can yarası (literally - soul wound). The difference between the body and soul is that the soul never ages and has no age at all: can kartaymıy (the soul never ages); the soul is freezing: can öşü; heating: can cılıta; burning: can yana, hurting: can äpnü, crying: can elau, moving: can çığu, can kız̆̆anu, can oçu, can kitü.

It should be noted that for the Tatar people can (soul) is the greatest treasure and wealth: can bäyase (literally - soul value), can (küñel) baylı̆̆ (soul wealth). 
The küñel word, whose meaning is close to those of can, is quite common in the Tatar language. The küñel word originated in the common Turkic vocabulary. Scholars believe that this word was derived from the Turkic basis köñ ("soul, chest"). R.G. Akhmetzyanov wrote in his dictionary: "the soul, the state of mind; mood" common Turkic köñül, könül ("soul, mood, chest"); in the Altai language - "to admire someone with a feeling of love"; in the Khakas language könni means "desire, the strength of spirit, mood", etc. (2001: 64).

It is worth mentioning that R.G. Akhmetzyanov singles out one more semantic basis for the küñel concept referring to it as a "breast". The dictionary notes, "The semantic meaning of the "chest" word is revealed in the Tatar phraseology "küñelsezgä külmäk kiyertmilär / they will not put a shirt on a moody one"; küñel açu / to have fun; küñel birep süyü / to love someone with all heart".

Thus, the küñel concept proves that the Turkic peoples put the soul into the chest. Therefore, the küñel lexeme relates to the words kükräk / chest, külmäk / shirt (dress) from the etymological viewpoint. This connection is crucial since modern scholars highlight the purely spiritual side of this concept without taking into account its historical meaning which is expressed by the following words: the mother's breast.

Summarising the ideas mentioned above, we can note that the küñel word has a wide information field in the Tatar language. It is evident from the "Defining dictionary of the Tatar language" that indicates eight meanings of this word. In addition, the idiomatical expressions associated with this word are represented on five pages. There are more than a hundred sayings and phraseological units with the küñel word. Moreover, this word can be used as different parts of speech. Thus, this concept has different semantic meanings and can express different cultural views. For instance, the küñel word as a noun has the following meanings:

1. The inner, spiritual world of people; their feelings, emotions.

2. The reason (basis) of mental state, emotions, feelings.

3. Thoughts, ideas, consciousness.

4. Mood, state.

5. Love, romantic feeling (Defining dictionary of the Tatar language, 1979).

We should note that the meanings of these words are quite different, and the lexeme mentioned above forms more than one hundred idiomatical expressions with them. Thus, the küñel concept has many meanings in the Tatar linguistic consciousness.

R.R. Zamaletdinov considers this concept as a stand-alone in his book on the reflection of the Tatar culture in the language. He notes that "this lexeme has no religious content, it is not connected with bodily vitality or the maintenance of the vital activity of an organism. This concept certainly belongs to nonequivalent vocabulary and can be translated conventionally into other languages as a soul or a heart" (2004: 74). The scholar is likely to have used the first meaning of this word marked in the Russian-Tatar dictionary since when a translated polysemous word cannot be marked as "nonequivalent".

In this regard, we should consult with the Tatar-Russian dictionary. There are seven meanings of the küñel lexeme that are similar to the meanings mentioned above provided by the explanatory dictionary:

"1. soul, heart (as the source of feelings); 2. the inner, spiritual world (of people); 3. mood, spirit; 4. thoughts, consciousness; 5. memory; 6. sympathy, love; 7. intuition, the soul".

In our opinion, an "internal state" and "inner feeling" are the best-suited notions since the küñel concept embraces a feeling, thought and consciousness. Later R.R. Zamaletdinov concludes that "... according to the everyday linguistic world image, künel is not a purely immaterial, spiritual formation; it is also the combination of material, even physical parameters, and characteristics of the intangible, ideal and spiritual nature. 
Küñel can be described as an internal topos, the inner space of a person, their inner world which is indicated by the compatibility of this word: küñel can be empty (küñel bushlugu), wide or narrow (kiñ, tatar küñel) that reflects greatheartedness. It can be opened (küñel açu, aculu, küñel kapkasun açu)" (Zamaletdinov, 2004: 83).

Thus, the küñel concept in the Tatar language, consciousness, and culture denotes the "inner feeling, thought, etc." of a person and the Tatar worldview.

Analyzing the reason for this polysemy, we should address the work of R.R. Zamaletdinov who notes that "it is necessary to compare küñel and can concepts to determine their role in the Tatar linguistic world-image. Due to their compatibility, these words can also have quite material qualities. In this case, zhan is more like a substance, while küñel is likely a topos. The combination of emotional and intellectual components in küñel is a significant difference between naive anatomy (E.V. Uruson's term) and modern psychology which divides emotional and intellectual spheres" (2004: 104).

Thus, the küñel lexeme refers to the spiritual world, thoughts, and experiences. Why did Tatars need such a semantically broad and synthesized lexeme? R.R. Zamaletdinov (relying on Uruson's opinion) believes it is the remnants of "naive views on anatomy", but we think historical views of the Tatar people and their cultural features should also be taken into consideration.

To prove this thesis, we should turn to another "nonequivalent" lexeme: moñ. This lexeme denotes "music, motive" and "sorrow, sadness". Neither musicians nor linguists do not describe this notion as "naive anatomy". Indeed, the Tatar people have many funny songs, but they are most know for long lyrical songs. It is not difficult to find the historical basis and cause of this phenomenon since historical songs preserve the people's suffering, their spiritual pain, and sorrow.

In our opinion, the formation of these synthetic and polysemic concepts was influenced by the historical habit of the people to simultaneously express in one lexeme thoughts, emotions, and feelings which is a special feature of the world perception of the Tatar people.

To support this opinion, we can also refer to the use of this concept in the small genre of the Tatar folklore, namely, in proverbs and sayings. The extensive use of the küñel concept in Proverbs is of particular interest since it reflects the spiritual experience of the people. As folklorist N. Isanbet points out, "All people have their own proverbs. For the most part, they do not reflect the socio-historical experience of the people, their beliefs and language capabilities. It is impossible to determine the exact time when they occurred since this process is continuing to this day. If the people still live, it means that the process will continue since people by nature are poets who convey their life experience conveys in creative works. Of course, it is the creation of one person while proverbs live in the people's memory, modify, generalize..." (1959: 9).

The phraseological dictionary compiled by N. Isanbet consists of 172 phraseological units with the küñel component. We have divided the following semantic groups:

1) Küñel - the state of mind, mood. These phraseological units denote lexical meanings related to the spiritual and inner world of a person, the transformation of their inner states and emotions. For example, küñel awış-täweş kilü / the instability of one's soul, uncertainty, impossibility to reach a certain decision; küñel alğisu / the soul's strive to something unconscious; küñel açu / to be glad, receive an esthetic pleasure, küñel bozlanu / the soul's cooling, life repudiation; küñel bozılu / the loss of humour, küñel ğazabı / spiritual torments, emotional stress.

2) Küñel - can: küñel barmıy / something does not appeal to someone, küñel tartu / emotional bond.

3) Küñel - relationship, love: küñel bizü / the soul's repudiation, antipathy, cooling in relations; küñel birü / to be interested, to take something to heart, to pay attention to something; küñel bolğanu / to give up on someone or something; küñelгä kerep utıru /

XLinguae, Volume 12, Issue 2, April 2019, ISSN 1337-8384, eISSN 2453-711X 
to be in a good soul, to regard someone as close; küñelгä xuş kilü / to be close to one's heart, to be in the mood; küñelrä yakın bulu / to like.

Romantic feelings in the Tatar language are described by the following word combinations: küñel koyashi - the sun of my soul; küñel yoldız - the star of one's soul; the bird of one's soul.

4) Küñel - memory, thought: küñelgä kilmägän / does not come to one's soul (cannot remember), töşkä kermägän / to have little dreams that (to elude, unexpectedness, extraordinary affair), küñelgä kilü / to come to one's soul (to remember), küñelgä señderü / to soak into one's soul (to memorise, learn by heart, keep in one's memory), küñeldä qalu - to leave in one's soul (to keep in one's memory), küñeldän kitmäü something does not leave one's memory (to keep in one's memory), küñeldän kiçerü - to put through one's soul (to revive a memory, recollect, remember), küñeldä saqlau / to keep in one's memory.

5) Küñel - inner world: küñel qaralu - soul blackening (one's soul becomes rough, mental split), küñel qatqan / one's soul becomes hardened (one's soul grows cold and brutal), küñel q1lları / mental strings (the mental state of a person, tender feelings).

They reflect the people's worldview, its generalized life experience arising from geographical and living conditions. The use of the küñel concept is also analyzed within the framework of the national world-image. We have disclosed the following semantic meanings of this concept.

First of all, they are used as a category relating to one's personality, the disclosure of one's inner world and spiritual life (Kayumova et al., 2019). Special attention in Proverbs is given to the resuscitation of the dignifying inner world of a person. The categories of beauty, morality, spiritual purity, responsiveness and other qualities of a person are regarded as truly national in proverbs. On the contrary, such categories as immorality, meanness, and betrayal are denied. They are later reflected in the following proverbs: Küñele turınıñ tele turı / The one with a righteous soul speaks the right language (to wear one's heart on the sleeve); Tele pıçraqniñ küñele pıçraq / The one who uses abusive language has a filthy soul; Tel küñelneñ közgese / One's language is the reflection of one's soul; Uqımıy qalğan - keşe xurı / The illiterate is a shame to the human race; Küñel kere äytsäñ betär, Külmäk kere yusañ betär / To get free from mental ties, you should share your grief - to clean off your shirt, you should wash it; Könçeneñ küñele tar bulır - A jealous person has a small heart (rather than big), etc.

The meaning of the küñel concept associated with the spiritual world of a person aims to praise and support certain qualities of a person's character and deny the others, which reflects the Tatar belief about an ideal person and moral categories that are valued by the people. In this regard, the künel concept is mainly associated with positive qualities of a person.

This concept often denotes thoughts and consciousness in Tatar proverbs. In this case, this concept is mainly used in the combination of words with the meaning of education or scholarship as opposed to someone uneducated. For example, Telen belän küñeleñne ber tot / do not tell something you are not sure about; Uqığanmı? dimä, uqığanın küñeleñä tuqığanmı? - digen / i.e., do not ask people whether they are educated, make sure that their soul has absorbed the knowledge; Ğalimneñ küñele okean diñgeze / the soul of a scientist is as broad as an ocean, etc.

The semantics of the küñel concept is also used in proverbs denoting a thought: Ana küñele balada, bala küñele dalada / the soul of a mother is in her child (she thinks about her child), the soul of a child is in the steppe (a child is interested in other worlds); Küñelgä kilgän ber närsäne söilämä / do not reveal everything that is on your soul, etc.

Tatar proverbs also use the concept küñel in the meaning of a mood: Yatim balanın küñele sınıq / an orphan has a broken soul; Cillätmi toman açılmıy / fog will not clear away without wind; Cirlamıy küñel açılmıy / a soul will not reveal itself without a 
song; Cır küñellegä quanıç / a song is a joy to a cheerful one, Küñelsezgä yuanıç / it is also a relief to the unemployed; Cirlap açılmasa küñel / if a soul does not reveal itself with a song, Elap açılaçaq tügel / it will not open with tears; Atam-anam biegän, Küñel açqan biyudän / our parents danced to relieve their feelings; Teatr - küñellärne uyatır / the theatre awakes souls.

The ability of this concept to reveal the person's state of mood is based on this exact meaning: Quyan elağanağa qarap, auçının küñele yomşarmas / if a hare cries, it will not soften a hunter's soul; Küñeleñ qalsa, kölkegä bor / if your soul was insulted, take it as a joke; Cyğa salsañ, su kütärmäs misqal timerne / water will not elevate even one gram of iron; Altın birep alıp bulmas qalğan küñelne / an insulted soul cannot be redeemed with gold; Keşe küñele - piyala, töşä dä uala / the soul of a person is like a glass, it can crack in no time.

The examples above are based on one meaning of the küñel concept, but express different shades of a person's mental state. Proverbs widely use another meaning of the küñel concept denoting a soul. For instance, Tuğan ilem - irkä gölem / my homeland, my soft flower, Kiñder siña küñel türem / I hold a special place for you in my soul; İlneñ cırı bar / A nation has a song, Küñelneñ moñı bar / while a soul has a melody; Köy - küñelneñ moñı / Music is the soul's melody; Tırış bala talpınğan qoştay / A diligent child is like a bird getting off the groud, Küñele tınmas küklärgä oçmıy / a soul will not rest if it does not take off; Könçeneñ küñelen yat bäxete yandıra / The soul of a jealous man is hurt by other's happiness; Waq яñğır tängä üтä / A drizzle chills a body, Waq süz - canğa üтä / while a little word can hurt a soul; Caylı süz can eretä / A kind word melts a soul; C1lı süz can azığı / A kind word is food for a soul, etc.

Therefore, tracing the semantic meaning of the küñel concept chosen for the analysis of Tatar proverbs, we have concluded that it has many meanings, including a soul, thought, content, mood, the state of mind, spiritual world, etc.

\section{Findings}

Phraseological units with emotionally valued semantics have been analyzed during the research.

According to the findings of this research, the boundaries between phraseological units and those with phraseological units containing emotionally valued semantics are not always sufficiently clear. Nevertheless, the context facilitated identification of the qualitative and quantitative composition of this category.

\section{Discussion}

This research showed that reflection of emotional conditions and specific features in the expression of emotion in the Tatar language phraseology is an indicator of the intellectual and emotional world of the Tatar people.

We see the prospects of further research into emotional expressions in the Tatar language in a more detailed study of the entire lexical system in an interlink with the folklore culture. This work can be used as a sample for further research in the field of lexicology, linguoculturology, and phraseology reflecting features of the history, culture and world outlook of the Tatar people.

\section{Conclusion}

The Tatar language phraseology is a reach thesaurus storing evaluations of human emotional states.

The soul is a substance of the human inner world. The "Soul" (can, künel, bawır) combined with such axiological and ethical categories as "life" and "love" denotes and actualizes the dominant features of the national character. 
"Can" is localized inside the human. The emotional side of the human is represented by such categories as «yöräk» (heart), «maturlık» (beauty), «ömet» (hope), «xlyal» (dream), «sağ $\iota s ̧ »$ (sadness), among which the concept of «mäxäbbät» (love) plays a special role. In the Tatar language phraseology with emotionally valued semantics, the conceptual notion includes the following: mental condition (mäxäbbättän künel elly the soul is crying from love); feeling (yöräktäge mäxäbbät - love inside the heart); physical sensation (mäxäbbätle karaş - amorous glance); existence of any space around the person (mäxäbbät dönyast - the world of love); as well as impersonation (canğa mäxäbbät kerü) - love emerged in soul.

In the human emotional concept-sphere, such notions as «xis», «toyğl», «kiçereş» play a significant role, and they are also represented as a fundamental vital value. The feeling of happiness is often accompanied by a sensation of soul enlightenment and the rise of vitality.

The research into phraseological units with emotionally valued semantics in the Tatar language makes it possible to characterize correctly and precisely the condition of the speaker and his/her environment. The emotional vocabulary can reflect the representation of human thoughts, emotions, and feelings resulting both from cognitive activities and from expressing real objects and phenomena. Thus, the people with their emotional condition, as well as its reflection in phraseology, form a necessary component for building the linguistic vision of the world.

Tatars' life and routines are significantly affected by the traditions and canons of Islam. These mental constructs were initially involved in the cognitive process; they reflected the structure of the universe in the mythological, and later in the religious consciousness of Tatars.

\section{Acknowledgments}

The work is performed according to the Russian Government Program of Competitive Growth of Kazan Federal University.

\section{Bibliographic references}

AHMETZYANOV R.G. 2001. Brief historical and etymological dictionary of the Tatar language. - The Tatar Book Publishers 129 p. (the Tatar language)

GILAZOV T.SH - KARABULATOVA I.S. - SAYFULINA F.S. - KURAKOVA CH.M. - TALIPOVA G.M. 2015. Between the East and the West: Phenomenon of Tartar Literary Criticism in the Lingvo-Cultural Aspect // Mediterranean Journal of Social Science. Vol 6, Issue 3, S2, pp. 508-517. ISSN: 2039-9340 Doi:10.5901/mjss.2015.v6n3s2p508

AYUPOVA R A. 2015. The role of paradoxes in the formation of a phraseological unit as a linguistic sign. Philology and Culture, Vol 4(42). pp. 35-40. ISSN: 20740239

BULGAROVA R. M. - ISLAMOVA E. A. 2017 Features of the functioning of the Turkisms in the comparisons of the Russian language. Philology and Culture, vol. 2 (48). pp. 24-31. ISSN: 2074-0239

DENMUKHAMETOVA E. N. 2016. Tatar phraseological units as an indicator of the identity of Tatars (on the example of phraseological units with geographic terms). Actual questions of research and teaching of native languages and literatures: a collection of materials of the International Scientific and Practical Conference. Cheboksary: The New Time: 66-72.

FAYZULLINA, G.CH. - KARABULATOVA, I.S. - FATTAKOVA A.A. ERMAKOVA, E.N. - SAYFULINA, F.S. 2016. The Anthropomorphous DollsPatrimonial Idols of Attanay and Their Place in the Language Picture World of the Siberian Tatars // The Social Science, issue 11, pp. 4448-4456. ISSN: 1818-5800

GABDRAKHMANOVA, F.H. - ZAMALETDINOV, R.R. - ZAMALETDINOVA, G.F. 2016. Comparative associative analysis of the meanings of the Tatar and English 
linguistic cultures (on the example of the Lexemes Gaila and family) // Journal of Language and Literature. Vol. 7, issue 3, August 2016, pp. 277-281. ISSN: 20780303 HUSNUTDINOV D.H. 2014. Tatar shigriyatenda avtor frazeologik beramleklarnen kullanilishi // Milli Medeniyet. - Afyonkarahisar-Qazan. issue 25. pp. 177-179.

HUSNUTDINOV D.H. - SAGDIEVA R.K. - MIRZAGITOV R.H. 2016. Comparative constructions in G. Ibragimov's works // Journal of Language and Literature. Vol.7, issue 4. - pp. 42-45. ISSN: 20780303

ISANBET N. 1959. About proverbs // Tatar folk proverbs. 1 vol. - Kazan: The Tatar Book Publishers., pp. 9-10. ISBN: 5-298-00255-2

IBRAGIMOV B. KH. - SAYFULINA F. S. - ABDYRASYLOVA G. K.TALIPOVA G. M. - FAIZOVA L. CH. 2017. Artistic-Style Features of Marat Kabirov's Intellectual Prose // Tarih Kültür ve Sanat Araştırmaları Dergisi, -Journal of History Culture and Art Research. Vol.6, issue 5 pp. 384-389, ISSN: 2147-0626 Available online: kutaksam.karabuk.edu.tr/index.php/ilk/article/view/1300/922

KAYUMOVA, G. - SHEYMARDANOV, S. - AKHTARIEVA, R. ZHUNDIBAYEVA, A. 2019 Developing creative potential of a schoolchild by means of native language. Journal of Social Studies Education Research, Vol. 10(1), pp. 8192.

KRASAVSKY N. A. 2016. Emotional concepts in German and Russian linguocultures. Moscow: Gnosis.

MUGTASIMOVA G. R. 2016. Tatar and Uyghur paremia as a source of ethnocultural information. Islam and the Turkic world: the problems of education, language, literature, history and religion: materials of the All-Russian Institute of Turkic Studies (Russia, Elabuga, April 22, 2016). Kazan: Publ.house Kazan.un-ta. pp. 254-256.

RODIONOVA G. A. 2011. Emotional abstract vocabulary in the language of M. Yu. Lermontov. The author's abstract. dis. ... cand. philol. sciences. Moscow. 23 p.

SALAKHOVA R. R. 2017. Peculiarities of the translation of emotive phraseological units. Paper presented at the Proceedings of the International Scientific and Practical Conference - Problems and prospects for the development of multilevel language training in a multicultural society (May 25-27, 2017). $458 \mathrm{p}$.

SHADRIKOV V. D. 2014. Introduction to psychology: emotions and feelings. Moscow: Logos.

SIBGAEVA, F.R. - ZAMALETDINOV R.R. - ZAMALETDINOVA G.F. 2015. Reflection of Tatar inner world through concepts // Journal of Language and Literature. Volume 6, no 3, pp. 115-118. ISSN: 20780303

YIĞIT M. F. - TARMAN B. 2016. How do different ethnicities approach to the education system and differences in turkey? Italian Sociological Review, Vol. 6(3) pp. 339-353. ISSN: 2239-8589 10.13136/isr.v6i3.119

ZAMALETDINOV R.R. 2004. Tatar culture in linguistic reflection. - M . Humanitarian Center "Vlados"; Kazan: Magarif. 175 p.

YUSUPOVA N.M. - SAYFULINA F.S. - GAINULLINA G. R - IBRAGIMOV B.KH. 2016. Fiction adaptation characteristics in tatar literature of the second half of XX century // European Journal of Science and Theology. February 2016, Vol.12, Issue 1, pp. 213-222. ISSN: 1842-8517 Available online: http://www.ejst.tuiasi.ro/issue12.html

Words: 5394

Characters: 34 577(19,21 standard pages)

Damir H. HUSNUTDINOV

Kazan Federal University

420008, Kazan, Kremlyovskaya Street, 18, Russian Federation

XLinguae, Volume 12, Issue 2, April 2019, ISSN 1337-8384, eISSN 2453-711X 
domer1982@mail.ru

Ramilya K. SAGDIEVA

Kazan Federal University

420008, Kazan, Kremlyovskaya Street, 18,

Russian Federation

Flera S. SAYFULINA

Kazan Federal University

420008, Kazan, Kremlyovskaya Street, 18

Russian Federation

Rinat G. GATIN

Kazan Federal University, Elabuga Institute of KFU,

Republic of Tatarstan, 423604, Elabuga, Kazanskaya Street, 89

Russian Federation

\section{Aynur A. TIMERKHANOV}

Kazan branch of the Russian State University of Justice, Department of Linguistics and Foreign Languages

Russian Federation 